\title{
Strategy for Enhancing Students' Entrepreneurship in Reducing Reduction in Knowledge Management's View
}

\author{
Hendra Utama
}

Lecturer of Faculty Social Science, Universitas Pembangunan Panca Budi, Medan, North Sumatera, Indonesia.

\begin{abstract}
This study aims to foster student strategies in developing entrepreneurship, which includes learning to do business, creativity in creating products, the promotion process, and innovations in developing business. The method used in this research is a qualitative approach with descriptive analysis to determine the students' strategies in starting and developing their business. This method is considered to be able to obtain as much detail as possible about student strategies in entrepreneurship. Based on the research results, it shows that students have high courage in entrepreneurship and self-taught learning via the internet. Data obtained from a survey conducted using a Google form filled with 56 students starting from the 2015-2019 class showed that students' strategies in developing business prefer social media as a means of product promotion because it is more effective and efficient. Based on the results of the study, we found a link between student entrepreneurial strategies and knowledge management. From the data we have collected, most of the students are self-taught, rely on information, and process that information. This is by the concept of knowledge management.
\end{abstract}

Keywords: knowledge management, entrepreneurship.

\section{INTRODUCTION}

Entrepreneurship comes from the term entrepreneurship which comes from the word entrepreneur, which means an ability (ability) in creative thinking and innovative behavior which is used as a basis, resources, driving force for goals, tactics, and processes in facing life's challenges (Munyua, 2017). According to research conducted through a Google form survey filled out by 56 students from various campuses, most of them agree that entrepreneurship can be learned self-taught not only by having to take entrepreneurship courses or have mentors who are experts in that field. The research method used is a qualitative approach with a descriptive analysis type. Data collection techniques conducted by researchers were using field observations, interviews, documentation, and a Google form survey which aims to determine student strategies in developing entrepreneurship (Schruben, 2010).

Knowledge management or knowledge management is a process of organizational change related to the knowledge that has not been included in the organization, including the acquisition, transformation, and distribution of information obtained and knowledge management needs to be linked to information management because knowledge management includes knowledge but cannot be managed without information management (Galih Prasetyo \& Muis, 2015). According to the above understanding, it can be concluded that the meaning of knowledge management is the art of processing information. There is a link between knowledge management and entrepreneurial strategy. According to the questionnaire we distributed via a Google form, $28.1 \%$ said they strongly agreed that entrepreneurship was learned through selfteaching and $56.1 \%$ said they agreed. From 
these data, it can be seen that entrepreneurial students try to process and learn information about entrepreneurship individually or by themselves, this is by the concept of knowledge management in processing information. Regarding student learning resources in entrepreneurship, from the data we collected, $36.6 \%$ agreed that respondents studied entrepreneurship via the internet and $63.2 \%$ strongly agreed about this. The purpose of this research is that we can find out the students' strategies in entrepreneurship and to find out the relationship between entrepreneurship and knowledge management (Warsono \& Ruksamin, 2014).

In addition, according to activity observers entrepreneurship (Entrepreneurial activity) is relatively low. Entrepreneurial activity is translated as an active individual in starting a business new and expressed as a percent of the total active population work. The lower the entrepreneurial activity index, the lower the level of entrepreneurship in a country, and its impact on high unemployment (Porumb et al., 2016).

The conditions above suggest how much trouble unemployment is a very serious problem. Several parties have questioned the existence of university graduates at this time. According to Hendarman, Director The Ministry of National Education's Higher Education Institution states "data educated unemployment in Indonesia shows that the higher a person's education, the more low in independence and entrepreneurial spirit." Entrepreneurial observers stated that most of the College graduates are more as a job seeker rather than a creator job field (job creator) (Aycan et al., 1999).

\section{LITERATUR REVIEW}

Entrepreneurship or entrepreneurship was originally a developed concept in the sociology and psychology traditions. At the beginning of the century 18th, Richard Cantillon, Irish-born scholar big companies in France, stated that entrepreneurship is a function of risk-bearing. One the following century, Joseph Schumpeter introduced the function of innovation as a powerful inner force of entrepreneurship. Since then, the concept of entrepreneurship is an accumulation of the function of courage to bear risk and innovation (Chisholm \& Fennes, 2006).

Entrepreneurship is a process of creativity and innovation that has a high risk for generate added value for products that are beneficial to society and bring prosperity to entrepreneurs. Entrepreneurship is the ability to see and assess business opportunities as well ability to optimize resources and take actions and risks to succeed in his business. Based on this definition entrepreneurship it can be learned by every individual have a desire, and are not just dominated talented individuals only (Hukum et al., 1960).

Entrepreneurship is the right choice for individuals who are challenged to create work, not looking for work.

- According to William Danko: "An entrepreneur (entrepreneur) has 4 opportunities times greater to be a millionaire".

- According to FORBES magazine: " $75 \%$ of 400 people America's richest businessman is an entrepreneur".

- The facts prove that many successful entrepreneurs have started small businesses (Prabawani et al., 2017)

Entrepreneurs are those who are brave in turning ideas into reality. According to Joseph Schumpeter, the entrepreneur is a person who perceives an opportunity and creates an organization to pursue it. Entrepreneurs are people who see opportunities, create an organization to take advantage of opportunities.

Based on this definition, personality an entrepreneur is identified by several researchers (Conference \& Business, 2017) as follows.

- Desire for responsibility, which is to have a taste big responsibility for that business just started. 
- Preference for moderate risk. Entrepreneurs take more risk into account. Entrepreneurs see business opportunities based on knowledge, their backgrounds, and experiences.

- Confidence in their ability to succeed. Entrepreneurs often have selfconfidence tall one. A study conducted by the National Federation of Independent Business (NFIB) suggests a third of entrepreneurs feel you have a $100 \%$ chance of being successful.

- Desire for immediate feedback. Entrepreneur Entrepreneurship or entrepreneurship was originally a developed concept in the sociology and psychology traditions. At the beginning of the century 18th, Richard Cantillon, Irish-born scholar big companies in France, stated that entrepreneurship is a function of risk-bearing. One the following century, Joseph Schumpeter introduced the function of innovation as a powerful inner force of entrepreneurship. Since then, the concept of entrepreneurship is an accumulation of the function of courage to bear risk and innovation (Siswoyo, 2009).

Entrepreneurship is a process of creativity and innovation that has a high risk for generate added value for products that are beneficial to society and bring prosperity to entrepreneurs. Entrepreneurship is the ability to see and assess business opportunities as well ability to optimize resources and take actions and risks to succeed in his business. Based on this definition entrepreneurship it can be learned by every individual have a desire, and are not just dominated talented individuals only.

Entrepreneurship is the right choice for individuals who are challenged to create work, not looking for work.

- According to William Danko: "An entrepreneur (entrepreneur) has 4 opportunities times greater to be a millionaire".
- According to FORBES magazine: " $75 \%$ of 400 people America's richest businessman is an entrepreneur".

- The facts prove that many successful entrepreneurs have started small businesses (Siswoyo, 2006).

Entrepreneurs are those who are brave in turning ideas into reality. According to Joseph Schumpeter, the entrepreneur is a person who perceives an opportunity and creates an organization to pursue it (Bygrave, 1994: 2). Entrepreneurs are people who see opportunities, create an organization to take advantage of opportunities.

Based on this definition, personality an entrepreneur is identified by several researchers (Siswoyo, 2006) as follows.

- Desire for responsibility, which is to have a taste big responsibility for that business just started.

- Preference for moderate risk. Entrepreneurs take more risk into account. Entrepreneurs see business opportunities based on knowledge, their backgrounds, and experiences.

- Confidence in their ability to succeed. Entrepreneurs often have selfconfidence tall one. A study conducted by the National Federation of Independent Business (NFIB) suggests a third of entrepreneurs feel you have a $100 \%$ chance of being successful.

- Desire for immediate feedback. Entrepreneur want to know how people respond other about the way they're running, and for that, they are delighted to receive input from others.

- High level of energy. Entrepreneurs are impressed has greater energy in comparison with most people.

- Future orientation. Entrepreneurs are endowed good ability in seeing a opportunity Entrepreneurship or entrepreneurship was originally a developed concept in the sociology and psychology traditions. At the beginning of the century 18th, Richard Cantillon, Irish-born scholar big companies in 
France, stated that entrepreneurship is a function of risk-bearing. One the following century, Joseph Schumpeter introduced the function of innovation as a powerful inner force of entrepreneurship. Since then, the concept of entrepreneurship is an accumulation of the function of courage to bear risk and innovation (Siswoyo, 2009).

Entrepreneurship is a process of creativity and innovation that has a high risk for generate added value for products that are beneficial to society and bring prosperity to entrepreneurs. Entrepreneurship is the ability to see and assess business opportunities as well ability to optimize resources and take actions and risks to succeed in his business. Based on this definition entrepreneurship it can be learned by every individual have a desire, and are not just dominated talented individuals only.

Entrepreneurship is the right choice for individuals who are challenged to create work, not looking for work.

- According to William Danko: "An entrepreneur (entrepreneur) has 4 opportunities times greater to be a millionaire".

- According to FORBES magazine: " $75 \%$ of 400 people America's richest businessman is an entrepreneur".

- The facts prove that many successful entrepreneurs have started small businesses (Siswoyo, 2006).

Entrepreneurs are those who are brave in turning ideas into reality. According to Joseph Schumpeter, the entrepreneur is a person who perceives an opportunity and creates an organization to pursue it (Bygrave, 1994: 2). Entrepreneurs are people who see opportunities, create an organization to take advantage of opportunities.

Based on this definition, personality an entrepreneur is identified by several researchers (Siswoyo, 2006) as follows.
- Desire for responsibility, which is to have a taste big responsibility for that business just started.

- Preference for moderate risk. Entrepreneurs take more risk into account. Entrepreneurs see business opportunities based on knowledge, their backgrounds, and experiences.

- Confidence in their ability to succeed. Entrepreneurs often have selfconfidence tall one.

- A study conducted by the National Federation of Independent Business (NFIB) suggests a third of entrepreneurs feel you have a $100 \%$ chance of being successful.

- Desire for immediate feedback. Entrepreneur want to know how people respond other about the way they're running, and for that, they are delighted to receive input from others.

- High level of energy. Entrepreneurs are impressed has greater energy in comparison with most people.

- Future orientation. Entrepreneurs are endowed good ability in seeing a opportunity want to know how people respond other about the way they're running, and for that, they are delighted to receive input from others.

- High level of energy. Entrepreneurs are impressed has greater energy in comparison with most people.

- Future orientation. Entrepreneurs are endowed good ability in seeing a opportunity

\section{METHODS}

This study uses quantitative research with descriptive analysis techniques, which is a research method for finding knowledge that uses data in the form of numbers as a tool to analyze information about what you want to know (Nazir, 1988). The descriptive method is examining an object or condition that aims to describe a phenomenon under study. In this study, the researcher acts as a key instrument with student research subjects at the State University of Malang. The type of research technique used is a 
Hendra Utama. Strategy for enhancing students' entrepreneurship in reducing reduction in knowledge management's view.

survey, namely, conducting investigations to obtain facts by evaluating and comparing the data or results that have been obtained.

The technique of collecting data is by distributing Goggle form data to students in each faculty at the State University of Malang to assist researchers in conducting research. Sugiono (2011) states that a questionnaire is a data collection technique by giving several questions to respondents. Researchers use students as samples in research subjects, according to Sugiyono (2010: 81) the sample is part of the number of characteristics of the population, the sample taken can truly represent the population, while the population is a collection of people, objects, or something of concern. . We use a quantitative approach in researching so that we can find out how the level of student satisfaction with the level of canteen cleanliness in each faculty.

\section{RESULTS}

The following describes the results of data descriptions from research respondents who have filled out the questionnaire in this study.

The year of the generation that filled out the questionnaire

\section{Years o generation}

\section{6 questioners}

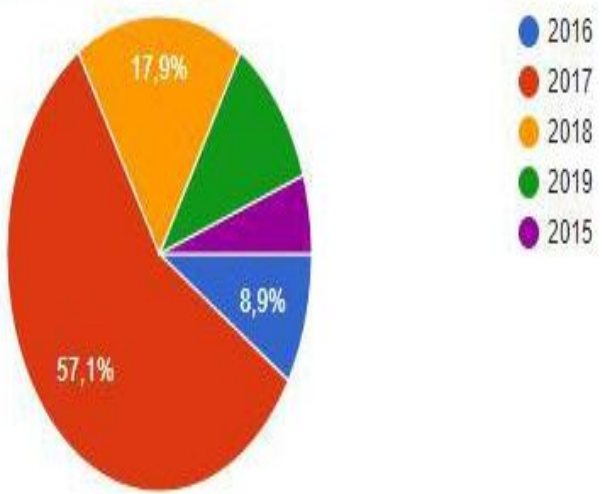

Figure 1. Chart of years generation

\section{Genders}

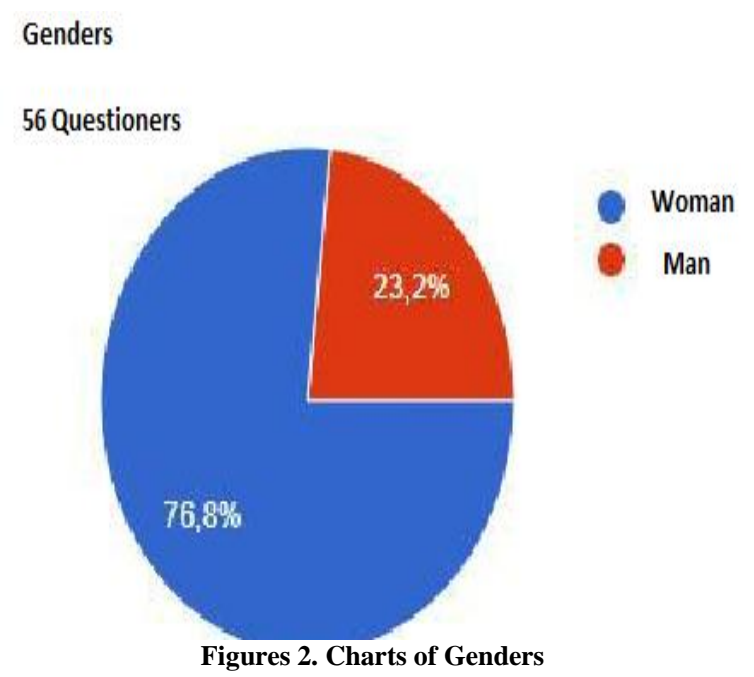

\section{Students learn entrepreneurship through social media / internet.}

\section{Questioners}

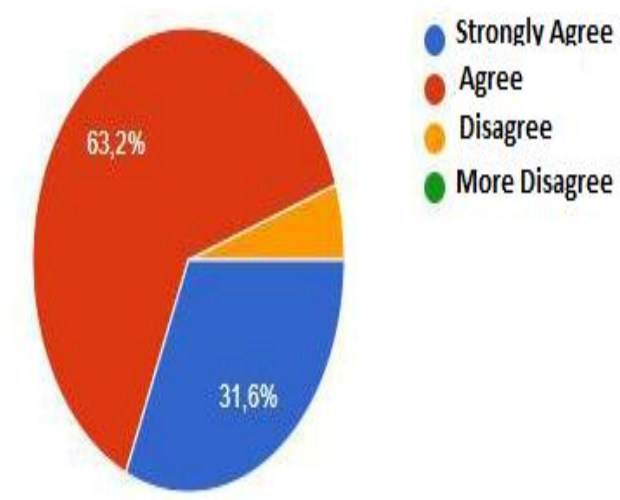

Figures 3. Learn Entrepreneurship Through Social Media / Internet

Based on the results of the data obtained from a survey conducted using a Google form, which was filled in by students from the year 2015-2019 as a resource, it shows that there are still many students who prefer to be self-taught, rely on social media in promoting products and making their brands.

From the survey data, many students rely on social media or the internet as learning materials for entrepreneurship. Because of that, many students rely more on courage in entrepreneurship. Survey data shows that students prefer social media as a means of product promotion because it is 
more effective and efficient. Students consider that a good product must be packaged attractively and have a brand, using discounts as a promotional event as well. Having good teamwork expand relationships and reduce the burden of entrepreneurship. From the survey data, many students admit that studying and entrepreneurship can be balanced and do not interfere with one another.

From the Google Form data survey that we have collected and recapitulated, there is a link between knowledge management and entrepreneurship development, example at this time, many students prefer entrepreneurship as an addition to their daily needs by using the concept of knowledge management, namely by self-taught learning via the internet. , rely on relationships as a means of product promotion and study them. This is by the concept of knowledge management which contains information processing and dissemination. (Sandhawalia \& Dalcher, 2011) entrepreneurship is not enough just to have assets and resources but also requires strong knowledge management competencies to develop and support work practices and business routines to remain competitive. (M. \& Bado, 2011) have a relationship between business partners and related parties that can support competitive work practices and business routines, so that a wide production and distribution network of products will be formed with a good partnership relationship.

From the data we collected, $28.1 \%$ said they strongly agreed that entrepreneurship was learned through selfteaching and $56.1 \%$ said they agreed. From these data, it can be seen that entrepreneurial students try to process and learn information about entrepreneurship individually or by themselves, this is by the concept of knowledge management in processing information. Regarding student learning resources in entrepreneurship, from the data we collected, $36.6 \%$ agreed that respondents studied entrepreneurship via the internet and $63.2 \%$ strongly agreed about this. (Awad \& Ghaziri, 2004) there are four basic patterns in creating knowledge, namely, socialization, externalization, combination and internalization, autodidactic learning via the internet, including the basic pattern of creating knowledge through internalization where a person carries out the process of sharing explicit knowledge from information on the internet then succeeds. converted into taxite knowledge for use in entrepreneurship.

In addition to entrepreneurial learning resources, according to the data we have collected, as many as $55.4 \%$ of correspondents strongly agree that they do marketing or promotion through social media, and $44.6 \%$ agree with this. According to Martin L. Bell in Basu (Private and Irawan, 1990) promotion is a marketing business activity to attract buyers. From these data, it can be concluded that in marketing correspondent products disseminate information and promote it through social media. This is considered to be the most effective and efficient way in today's modern era. In disseminating information, the correspondent indirectly carries the concept of knowledge management in the information dissemination process.

\section{CONCLUSION}

In entrepreneurship, students often rely on the internet as a reference for learning and obtaining important related information. This is in tune with or related to the concept of knowledge management in the process of processing information. This can be applied effectively and efficiently considering that the era is all technological, it is also about promotion and can easily determine the target market through social media.

The hope is that when this technological era becomes easy, students do not arbitrarily receive information; it must be processed and researched properly as in the concept of knowledge management where information received before 
Hendra Utama. Strategy for enhancing students' entrepreneurship in reducing reduction in knowledge management's view.

processing must ensure the validity of the information received.

\section{Acknowledgement: None}

\section{Conflict of Interest: None}

\section{Source of Funding: None}

\section{REFERENCES}

1. Aycan, Z., Kanungo, R. N., \& Sinha, J. B. P. (1999). Organizational culture and human resource management practices: The model of culture fit. Journal of Cross-Cultural Psychology, 30(4), 501-526. https://doi.org/10.1177/0022022199030004 006

2. Chisholm, L., \& Fennes, H. (2006). Competence development as workplace learning in Asia and Europe: Introduction Background and context of this publication. Innsbruck University Press.

3. Conference, G., \& Business, O. N. (2017). 6th Global Conference On Business \& Social Sciences Conference Program.

4. Galih Prasetyo, A., \& Muis, A. (2015). Pengelolaan Keuangan Desa Pasca UU No. 6 Tahun 2014 Tentang Desa: Potensi Permasalahan dan Solusi. Jurnal Desentralisasi, 13(1), 16-31.

5. Hukum, P., Humas, D. a N., \& Hukum, S. (1960). Pusat hukum dan humas sjdi hukum. 5-7.

6. Munyua, M. N. (2017). the International Journal of Business \& Management. Mediating Effect of Self- Efficacy on
Experimental Learning and Entreprenurial Intention Among Physically Challenged Studentsin Kenya: A Case Study of Nairobi County, Kenya, 5(8), 134-145.

7. Porumb, C., Cluj-napoca, U. T., Orza, B., \& Cluj-napoca, U. T. (2016). Blended Learning Concept and its Applications to Engineering Education Cosmin Porumb , Sanda Porumb , Bogdan Orza and Aurel Vlaicu. March. https://doi.org/10.4028/www.scientific.net/ AEF.8-9.55

8. Prabawani, B., Seno, A. H. D., Waloejo, H. D., Hanika, I. M., \& Werdani, R. E. (2017). Socialization: an important factor of redenomination success in Indonesia. In 6th Global Conference on Business and Social Sciences.

9. Schruben, L. (2010). Simulation modeling for analysis. ACM Transactions on Modeling and Computer Simulation, 20(1), $1-22$.

https://doi.org/10.1145/1667072.1667074

10. Warsono, H., \& Ruksamin, D. (2014). The Obstacles of Implementation of Village Allocation Fund Program in the North Konawe Southeast Sulawesi. Journal of Management and Sustainability, 4(3), 175183. https://doi.org/10.5539/jms.v4n3p175

How to cite this article: Utama H. Strategy for enhancing students' entrepreneurship in reducing reduction in knowledge management's view. International Journal of Research and Review. 2021; 8(5): 292-298. DOI: https://doi. org/10.52403/ijrr.20210537 